\title{
FAKTOR-FAKTOR YANG MEMPENGARUHI MINAT SISWA KELAS IX SMP PGRI TAMBUN SELATAN MELANJUTKAN STUDI KE SEKOLAH MENENGAH KEJURUAN
}

\author{
Fika Rizki Febriyanti ${ }^{1}$ \\ Dra. Atiek Sismiati $\mathbf{S}^{2}$ \\ Drs. Djunaedi, M. Pd ${ }^{3}$
}

\begin{abstract}
Abstrak
Penelitian ini bertujuan untuk memperoleh gambaran faktor-faktor yang mempengaruhi minat siswa SMP PGRI Tambun Selatan yang melanjutkan studi ke sekolah menengah kejuruan. Metode yang digunakan adalah metode deskriptif dengan jenis penelitian survei. Populasi dalam penelitian ini adalah siswa kelas IX SMP PGRI Tambun Selatan yang memiliki minat melanjutkan studi ke SMK sebanyak 165 siswa. Teknik sampling yang digunakan dalam penelitian adalah sampling jenuh dengan jumlah sampel dalam penelitian ini diambil dari semua anggota populasi yaitu sebanyak 165 siswa. Uji coba instrumen berisikan 48 butir pernyataan yang diberikan kepada 46 responden. Hasil perhitungan uji validitas diperoleh 33 butir pernyataan yang valid dan 15 butir pernyataan yang drop. Uji reliabilitas terhadap butir pernyataan yang valid memperoleh hasil sebesar 0,858. Angka tersebut menunjukan bahwa instrumen yang digunakan mempunyai reliabilitas yang sangat tinggi. Penelitian ini menggunakan analisa deskriptif presentase untuk menggambarkan faktor-faktor yang mempengaruhi minat siswa kelas IX SMP PGRI Tambun Selatan melanjutkan studi ke SMK. Hasil penelitian menunjukan bahwa faktor yang mempengaruhi minat melanjutkan studi ke SMK adalah faktor dorongan dari dalam (The Factor of Inner Urges) sebesar 26.52\%, faktor motif sosial (The Factor of Social Motive) sebesar 37.96\%, dan faktor emosional (Emosional Factors) dengan persentase sebesar 35.53\%. Kesimpulan penelitian ini adalah siswa kelas IX SMP PGRI Tambun Selatan yang minat melanjutan studi ke sekolah menengah kejuruan didominasi oleh faktor motif sosial (The Factor of Social Motive). Implikasi dari hasil penelitian ini adalah Guru BK memaksimalkan peranan dengan melakukan strategi penyelenggaraan pela-yanan bimbingan karir dan memaksimalkan kompetensi siswa sesuai dengan minat yang dimilikinya.
\end{abstract}

Kata kunci : Faktor-faktor yang mempengaruhi minat, Siswa SMK

\footnotetext{
Mahasiswa Jurusan Bimbingan dan Konseling FIP UNJ, fikarizkifebriyanti@gmail.com

2 Dosen Bimbingan dan Konseling FIP UNJ, atiek.sismiati@yahoo.com

3 Dosen Bimbingan dan Konseling FIP UNJ, djunaediunj@yahoo.co.id
} 


\section{Pendahuluan}

Masyarakat Ekonomi ASEAN (MEA) yang akan dilaksanakan pada tahun 2015 merupakan kerjasama di negara-negara Asia Tenggara dalam rangka untuk meningkatkan ekonomi masing-masing negara yang kemudian diharapkan dapat mengurangi kemiskinan dan kesenjangan ekonomi diantara negara-negara anggotanya melalui sejumlah kerjasama yang saling menguntungkan. Hadirnya Masyarakat Ekonomi Asean (MEA) ini memaksa Indonesia sebagai salah satu negara yang berada di Asia Tenggara untuk memperkuat daya saing dalam segala bidang terutama dalam bidang ketenagakerjaan. Tidak dapat dipungkiri persaingan dalam ketenagakerjaan menghadapi MEA ini membutuhkan Sumber Daya Manusia (SDM) yang berkualitas atau dengan kata lain menyerap lulusan yang terampil di bidangnya.

Lulusan yang disesuaikan dengan bidang pekerjaan dan dipersiapkan untuk langsung bekerja adalah lulusan sekolah menengah kejuruan. Pendidikan kejuruan menyangkut pengembangan sosial tenaga kerja masyarakat, berupa peningkatan, percepatan, dan penciptaan kualitas tenaga kerja dalam bidang tertentu untuk meningkatkan daya produksi masyarakat. Sebaliknya, berbeda dengan lulusan sekolah menengah atas yang memang dipersiapkan untuk melanjutkan pendidikan ke jenjang yang lebih tinggi. Namun, yang terjadi saat ini para lulusan sekolah menengah atas tersebut justru banyak yang langsung bekerja. Hal ini seharusnya dipersiapkan sejak awal sehingga memiliki persiapan yang cukup untuk memasuki dunia kerja.

Data lain yang diperoleh dari Badan Pusat Statistik (BPS) pada Agustus 2013 membuktikan bahwa jumlah pengangguran terbuka yang berasal dari lulusan sekolah menengah atas mencapai angka 1.925 .563 orang atau sekitar $60 \%$, sedangkan untuk pengangguran terbuka yang berasal dari sekolah menengah kejuruan mencapai angka 1.259.444 orang atau sekitar $40 \%$ dari total pengangguran terbuka untuk tingkat pendidikan menengah. Kondisi ini menyimpulkan banyaknya pengangguran terbuka lulusan sekolah menengah atas dibandingkan dengan sekolah menengah kejuruan. Oleh karena itu, kenyataan tersebut diharapkan bagi seluruh masyarakat Indonesia untuk selalu berusaha meningkatkan Sumber Daya Manusia (SDM) yang berkual- itas dan salah satu cara meningkatkan kualitas SDM dengan melalui jalur pendidikan. Pendidikan diharapkan dapat berperan dalam meningkatkan kualitas para lulusannya menjadi lebih baik untuk mampu menguasai ilmu pengetahuan dan perkembangan teknologi yang dibutuhkan dalam membangun bangsa.

Melalui jalur pendidikan dalam menghadapi laju angka pengangguran lulusan sekolah menengah atas yang meningkat dan kurangnya peminat sekolah menengah kejuruan, pemerintah mengarahkan minat siswa agar masuk ke sekolah menengah kejuruan sesuai dengan Rencana Strategis (Renstra) Departemen Pendidikan Nasional 2006-2020 menyatakan bahwa pada masa yang akan datang sekolah menengah kejuruan akan menjadi salah satu komponen pendidikan yang perlu dikembangkan di Indonesia. Bahkan telah diprediksikan beberapa tahun yang akan datang jumlah sekolah menengah kejuruan lebih banyak dibandingkan dengan sekolah menengah atas. Selain itu juga, usaha pemerintah melalui jalur pendidikan dalam mengarahkan siswa untuk melanjutkan ke sekolah menengah kejuruan terlihat dari upaya strategi yang dilakukan untuk menyakinkan masyarakat terutama siswa lulusan sekolah menengah pertama agar lebih berminat memilih pendidikan kejuruan dalam menempuh karir pendidikan le-bih lanjut. Salah satunya dengan tayangan iklan mengenai sekolah menengah kejuruan di media televisi, iklan tersebut dibuat semenarik mungkin agar dapat memberikan gambaran kepada para siswa sekaligus menarik minat mereka agar mau melanjutkan studi ke jenjang pendidikan sekolah menengah kejuruan setelah lulus.

Sekolah menengah kejuruan merupakan salah satu bentuk satuan pendidikan formal yang menyelenggarakan pendidikan kejuruan pada jenjang pendidikan menengah sebagai lanjutan dari sekolah menengah pertama, madrasah tsanawiyah, atau bentuk lain yang sederajat. Selain itu, dapat diartikan bahwa sekolah menengah kejuruan adalah satuan pendidikan yang menyiapkan peserta didik agar dapat bekerja, baik secara mandiri atau mengisi lowongan pekerjaan yang ada di dunia usaha dan industri sebagai tenaga kerja tingkat menengah, sesuai dengan bidang dan program yang diminati dan membekali peserta didik agar mampu memilih karir, ulet dan 
gigih dalam berkompetisi di dunia kerja. Berdasarkan pandangan mengenai sekolah menengah kejuruan, maka perlu diketahui alasan, tujuan, dan halhal yang melatarbelakangi siswa sekolah menengah pertama merencanakan memilih sekolah menengah kejuruan tersebut salah satunya adalah minat.

Slameto (2010) mengemukakan, bahwa "Minat adalah suatu rasa lebih suka dan rasa keterikatan pada suatu hal atau aktivitas, tanpa ada yang menyuruh. Sejalan dengan pendapat tersebut teori Skinner dalam Djamarah (2008) minat selalu berhubungan dengan obyek yang menarik individu dan obyek yang menarik adalah yang dirasakan menyenangkan. Jika seorang siswa merasa tertarik belajar merakit robot, maka ia akan senang melakukannya sampai robot itu terbentuk. Apabila seseorang mempunyai minat terhadap suatu obyek maka minat itu akan mendorong seseorang untuk berhubungan lebih dekat dengan obyek tersebut, yaitu dengan melakukan aktivitas lebih aktif dan positif demi mencapai sesuatu yang diminatinya. Begitu juga dalam hal minat melanjutkan studi, semua berkaitan dengan sesuatu yang ingin dicapai dari siswa tersebut. Kebijakan yang telah dibuat oleh pemerintah akan jauh dari harapan, jika minat melanjutkan studi ke sekolah menengah kejuruan masih rendah. Permasalahan yang berkaitan dengan minat tersebut tidak terlepas dari adanya faktor-faktor yang mempengaruhi minat siswa melanjutkan studi ke sekolah menengah kejuruan.

Sekolah menengah pertama merupakan jenjang pendidikan dasar pada pendidikan formal di Indonesia setelah menyelesaikan pendidikan sekolah dasar atau sederajat. Siswa sekolah menengah pertama umumnya berada dalam rentang usia antara 12-14 tahun, atau dalam usia remaja yang berada dalam tahap kapasitas yang dengan kata lain menurut Ginzberg dalam Fatimah (2010) pada tahap ini mereka telah matang untuk mulai menggunakan keterampilan dan kemampuan pribadinya sebagai pertimbangan untuk menghasilkan pilihan-pilihan sesuai pola pikir yang dimilikinya.

Begitupun dalam melanjutkan studi ke sekolah lanjutan, siswa sekolah menengah pertama terutama siswa kelas IX sebelum dan sesudah melaksanakan ujian kelulusan akan dihadapkan pada dua pilihan sekolah lanjutan, yaitu sekolah menengah atas dan sekolah menengah kejuruan. Bagi siswa sekolah menengah pertama kelas IX yang berencana memilih studi lanjutan ke sekolah menengah atas kemungkinan tidak ada masalah dalam menentukan tujuan, karena pendidikan di sekolah menengah atas masih bersifat umum, namun sebaliknya dengan siswa sekolah menengah pertama kelas IX yang berencana memilih studi lanjutan ke sekolah menengah kejuruan akan dihadapkan pada berbagai pilihan bidang keahlian yang ditawarkan sekolah menengah kejuruan. Maka dari itu, diperlukan keterampilan dan kemampuan siswa sekolah menengah pertama kelas IX untuk menghasilkan pilihan yang sesuai dengan dirinya.

Studi pendahuluan berupa angket sekolah lanjutan dan wawancara yang telah dilakukan kepada guru Bimbingan dan Konseling SMP PGRI Tambun Selatan diperoleh data bahwa jumlah siswa kelas IX yang merencanakan melanjutkan studi lanjut ke sekolah menengah kejuruan sebanyak 165 siswa dari jumlah keseluruhan siswa kelas IX sebanyak 309 siswa. Data tersebut menunjukan bahwa minat siswa kelas IX SMP PGRI Tambun Selatan yang berencana melanjutkan ke sekolah menengah kejuruan cenderung lebih banyak dibandingkan de-ngan minat siswa untuk melanjutkan studi ke sekolah menengah atas atau sederajat.

Selanjutnya, berdasarkan wawancara dengan salah satu guru Bimbingan dan Konseling SMP PGRI Tambun selatan diperoleh informasi bahwa minat siswa lulusan SMP PGRI Tambun Selatan dari tahun ke tahun cenderung meningkat untuk melanjutkan studi ke sekolah menengah kejuruan. Hal itu terlihat dari minat beberapa siswa yang merencanakan melanjutkan studi ke sekolah menengah kejuruan dengan alasan agar bisa mengembangkan kemampuannya dan memperdalam keahlian seperti di bidang otomotif, bidang farmasi dan bidang lainnya. Selain itu, beberapa siswa yang minat melanjutkan ke sekolah menengah kejuruan beralasan dengan masuk ke sekolah menengah kejuruan bisa memperoleh pengalaman dalam dunia kerja dengan mengikuti kegiatan Praktek Kerja Lapangan (PKL) .

Di samping itu juga, beberapa siswa merencanakan melanjutkan studi ke sekolah menengah kejuruan dikarenakan saran yang diberikan oleh orangtuanya untuk melanjutkan studi ke sekolah menengah kejuruan dengan harapan setelah lulus bisa 
segera bekerja. Hal itu terjadi karena sebagian besar siswa SMP PGRI Tambun Selatan berasal dari keluarga dengan tingkat ekonomi menengah ke bawah. Sehingga tidak mengherankan setelah anaknya menamatkan pendidikan di sekolah menengah pertama, orang tuanya menuntut anaknya untuk melanjutkan studi lanjutan ke sekolah menengah kejuruan dengan harapan agar bisa lebih cepat bekerja dan membantu perekonomian keluarga.

Berdasarkan hal-hal yang telah diuraikan maka rumusan masalah dalam penelitian ini yaitu "Bagaimana gambaran faktor-faktor yang mempengaruhi minat siswa kelas IX SMP PGRI Tambun Selatan untuk melanjutkan studi ke sekolah menengah kejuruan?

Tujuan dari penelitian ini adalah untuk memberikan gambaran secara empiris tentang faktor-faktor yang mempengaruhi minat siswa kelas IX SMP PGRI Tambun Selatan untuk melanjutkan studi ke sekolah menengah kejuruan

\section{Kajian Teori}

\section{Faktor-faktor yang Mempengaruhi Minat}

Sukardi (1998) mengemukakan bahwa minat merupakan suatu kesukaan, kegemaran, atau kesenangan akan sesuatu. Slameto (2010) turut menambahkan pendapat diatas, menurutnya minat adalah suatu rasa lebih suka dan rasa ketertarikan pada suatu hal atau aktivitas, tanpa ada yang menyuruh. Minat pada dasarnya adalah penerimaan akan suatu hubungan antara diri sendiri dengan sesuatu di luar diri. Semakin kuat atau dekat hubungan tersebut, semakin besar minat.

Menurut Crow \& Crow (1961) ada beberapa faktor yang mempengaruhi minat, faktor-faktor tersebut adalah sebagai berikut:

1) Dorongan dari dalam (The Factor Inner Urge), yaitu mengarah pada kebutuhan-kebutuhan yang muncul dari dalam individu merupakan faktor yang berhubungan dengan dorongan fisik, motif, mempertahankan diri dari rasa lapar, rasa takut, rasa sakit, juga dorongan ingin tahu membangkitkan minat untuk mengadakan penelitian.

2) Motif sosial (The Factor Of Social Motive), yaitu mengarah pada penyesuaian diri dengan lingkungan agar dapat diterima dan diakui oleh ling- kungan atau aktivitas untuk memenuhi kebutuhan sosial, seperti bekerja, mendapatkan status, mendapatkan perhatian dan penghargaan

3) Emosional (Emotional Factors), yaitu minat yang erat hubungannya dengan perasaan atau emosi, keberhasilan dalam beraktivitas yang didorong oleh minat akan membawa rasa senang dan memperkuat minat yang sudah ada, sebaliknya kegagalan akan mengurangi minat individu tersebut.

\section{Metode Penelitian}

Metode penelitian yang digunakan dalam penelitian ini adalah metode deskriptif dengan jenis penelitian survey. Menurut Margono (2007) tujuan penelitian survey untuk mengambil suatu generalisasi dari gambaran sifat keadaan yang berlangsung pada saat penelitian dilaksanakan serta memeriksa sebabsebab dari gejala tertentu. Subjek penelitian yaitu seluruh siswa kelas XI SMP PGRI Tambun Selatan yang minat untuk melanjutkan studi ke sekolah menengah kejuruan, yaitu 165 siswa. Teknik sampling yang digunakan adalah teknik sampling jenuh atau disebut juga sensus. Sampel dalam penelitian ini adalah seluruh siswa kelas XI SMP PGRI Tambun Selatan yang minat untuk melanjutkan studi ke sekolah menengah kejuruan, yaitu 165 siswa.

Penelitian ini dilakukan terhitung sejak bulan Februari sampai dengan bulan Desember 2014 dan dilaksanakan di SMP PGRI Tambun Selatan, Bekasi Timur.

Teknik pengumpulan data yang digunakan dalam penelitian ini adalah melalui penyebaran kuesioner dengan menggunakan skala Likert dengan lima pilihan jawaban. Sebelum instrumen digunakan, dilakukan uji coba terlebih dahulu kepada 46 orang siswa kelas IX SMP PGRI Tambun Selatan untuk mengukur tingkat validitas dan reliabilitas instrumen. Hasil pengujian validitas butir yaitu menyatakan sebanyak 33 butir pernyataan valid dan 15 drop. Hasil perhitungan reliabilitas dengan rumus Alpa Croncbach diperoleh koefesien reliabilitas sebesar 0,858 . Teknik analisis data yang digunakan pada penelitian ini adalah deskriptif persentase karena penelitian ini hendak memberikan gambaran mengenai faktor-faktor yang mempengaruhi minat siswa kelas IX SMP PGRI Tambun Selatan melanjutkan studi ke sekolah 
menengah kejuruan.

\section{Hasil dan Pembahasan}

Hasil penelitian secara keseluruhan menunjukan bahwa faktor-faktor yang mempengaruhi minat siswa melanjutkan ke sekolah menengah kejuruan dipengaruhi oleh faktor dorongan dari dalam (The Factor of Inner Urges) yang memberikan kontribusi sebesar 26.52\%, faktor motif sosial (The Factor of Social Motive) sebesar 37.96\%, dan faktor emosional (Emosional Factors) yang memberikan kontribusi sebesar $35.53 \%$. Hasil secara rinci disajikan pada tabel berikut ini:

Tabel 1

Data Faktor-Faktor yang Mempengaruhi Minat Melanjutkan Studi ke Sekolah Menengah Kejuruan pada Siswa SMP PGRI Tambun Selatan

\begin{tabular}{|c|c|c|c|}
\hline Faktor & $\boldsymbol{\Sigma}$ Item & $\boldsymbol{\Sigma}$ Per-Faktor & Persentase \\
\hline $\begin{array}{c}\text { Dorongan dari dalam } \\
\text { (The Factor of Inner Urges) }\end{array}$ & 9 & 5639 & $26.52 \%$ \\
\hline $\begin{array}{c}\text { Motif Sosial } \\
\text { (The factor Of Social Motive) }\end{array}$ & 12 & 8072 & $37.96 \%$ \\
\hline $\begin{array}{c}\text { Emosional } \\
\text { (Emosional Factors) }\end{array}$ & 12 & 7556 & $35.53 \%$ \\
\hline Jumlah & $\mathbf{3 3}$ & $\mathbf{2 1 2 6 7}$ & $\mathbf{1 0 0 \%}$ \\
\hline
\end{tabular}

Berdasarkan hasil penelitian yang diperoleh dari data faktor-faktor yang mempengaruhi minat melanjutkan studi ke sekolah menengah kejuruan ditemukan bahwa faktor yang mempengaruhi dan memberikan kontribusi terbesar dalam minat siswa kelas IX SMP PGRI Tambun Selatan melanjutkan studi ke sekolah menengah kejuruan dengan persentase tertinggi berada pada faktor motif sosial (The Factor of Social Motive) dengan persentase sebesar 37.96\%. Diketahui bahwa pada faktor ini menunjukan pandangan dan sikap siswa dalam pemenuhan kebutuhan sosial dengan berupaya mempunyai sikap optimis yang tinggi mengenai ketertarikannya belajar di sekolah menengah kejuruan untuk mendapatkan pengalaman dan keterampilan yang dibutuhkan dunia kerja saat ini guna mempunyai peluang yang besar untuk mendapatkan pekerjaan. Di samping itu juga, kecenderungan siswa tertarik melanjutkan ke sekolah menengah kejuruan karena tuntutan dari orangtua untuk segera bekerja demi membantu perekonomian keluarga. Tingkat ekonomi orang tua yang rendah membuat siswa sekolah menengah pertama cenderung mengurungkan niatnya untuk melanjutkan pendidikan ke sekolah menengah atas.

Faktor berikutnya yang turut mempengaruhi minat siswa melanjutkan studi ke sekolah menengah kejuruan adalah faktor emosional (Emosional Factors) dengan persentase sebesar 35.53\%. Faktor emosional (Emosional Factors) mampu mempengaruhi minat siswa melanjutkan studi ke sekolah menengah kejuruan. Ini menunjukan kecenderungan siswa memiliki perasaan senang dan bersemangat untuk melanjutkan studi ke sekolah menengah kejuruan. Ini terlihat dengan kegiatan siswa yang senang membaca brosur-brosur sekolah menengah kejuruan dan siswa senang membaca catatan teman yang belajar di sekolah menengah kejuruan, serta siswa senang apabila memperoleh arahan dari orang tua dan saudara untuk melanjutkan ke sekolah menengah kejuruan.

Faktor terakhir yang turut mempengaruhi minat siswa melanjutkan studi ke sekolah menengah kejuruan adalah faktor dorongan dari dalam (The Factor of Inner Urges) dengan persentase sebesar 26.52\%. Mengenai faktor dorongan dari dalam (The Factor of Inner Urges) ternyata pada siswa kelas IX SMP PGRI Tambun Selatan memiliki kontribusi yang berada dibawah faktor-faktor lainnya. Pada faktor dorongan dari dalam (The Factor of Inner Urges) ini memberikan pengaruh rasa ingin tahu pada diri siswa mengenai ketertarikannya melanjutkan studi ke sekolah menengah kejuruan. Ini terlihat siswa sudah merencanakan melanjutkan sekolah ke sekolah menengah kejuruan dan sudah menentukan sekolah menengah kejuruan yang akan di masuki setelah lulus sekolah menengah pertama, serta siswa memfokuskan diri untuk lebih tahu pada bidang studi yang diinginkan untuk memilih jurusan di sekolah menengah kejuruan.

\section{Simpulan dan Saran}

Secara keseluruhan faktor yang memberikan kontribusi terbesar dalam

\section{Guru BK}

Guru Bimbingan dan Konseling dapat secara berkelanjutan meningkatkan layanan kepada siswa khususnya dalam aspek karir dengan menggunakan hasil penelitian ini yang mengidentifikasi dominasi faktor motif sosial (The Factor of Social Motive) dalam mempengaruhi minat 
siswa melanjutkan studi ke sekolah menengah kejuruan. Guru BK juga dapat memberikan informasi karir khususnya tentang sekolah lanjutan secara komperhensif dalam proses pembelajaran melalui layanan bimbingan klasikal, bimbingan kelompok, seminar/workshop.

\section{Bagi Orangtua}

Berdasarkan hasil penelitian, maka saran untuk orangtua adalah agar orangtua memberikan motivasi baik berupa pujian atau penghargaan serta arahan kepada anak atas minat yang dimilikinya dalam melanjutkan studi ke sekolah menengah kejuruan yang sesuai dengan potensi yang ada dalam dirinya.

\section{Bagi Siswa}

Siswa mampu memaksimalkan informasi karir yang diberikan oleh sekolah dengan bertanya kepada guru BK mengenai sekolah lanjutan serta siswa juga dapat mencari tahu tentang sekolah lanjutan melalui media massa maupun online untuk dapat menentukan pilihan yang tepat dan sesuai dengan minat dan kemampuan yang dimiliki, agar dikemudian hari tidak ada penyesalan.

\section{Bagi Peneliti Selanjutnya}

Peneliti menyarankan agar pada penelitian lain dengan subjek penelitian faktor yang mempengaruhi minat siswa melanjutkan studi ke sekolah menengah kejuruan memberikan program secara teknis untuk aplikasi penyelenggaraan pelayanan bimbingan dan konseling khususnya mengenai bimbingan karir.

\section{Daftar Pustaka}

Clarke Linda. (2007). Vocational Education: International Approaches, Developmentsand Systems; The Emergenceand Reinforcement of Class and Gender Divisions Through Vocational Education, in England. New York: Routledge

Crow and Crow. (1961). An Outline of General Psychology, New Jersey: Littlefield, adams \& co

Dewa Ketut Sukardi. (1998). Bimbingan dan Konseling, Jakarta: Bina Aksara

Direktorat Jendral Pendidikan Islam Departemen Agama RI. 2006. Undang-Undang dan Peraturan Pemerintah RI tentang Pendidikan

Subijanto. (2007). Pengembangan Sekolah Menengah Kejuruan pada Otonomi Daerah, Jurnal Pendidikan dan Kebudayaan Edisi Khusus I Tahun ke 13: Agustus

Syamsir Alam. (2008). SMK jembatan sekolah dan dunia kerja, (http://www.mediaindonesia.com/index php?ar_kl=MjA5NDI=), diakses tanggal 15 Agustus 2014 pada 05.10 WIB 